\title{
DISPUTE SETTLEMENT BODY - WTO DALAM PENYELESAIAN SENGKETA PERDAGANGAN INTERNASIONAL
}

\author{
Ade Maman Suherman ${ }^{1}$
}

\begin{abstract}
The more intensenya international trade has led to an increase in tension that cause trade disputes between nations, both in trade in goods and services. This study focuses on the procedural issue is how the dispute settlement mechanism of the WTO DSB-through, and how the involvement of developed and developing countries in international trade disputes, and how the role of the WTO DSB in dispute resolution. This research approach approach the statue memngetahui trade dispute settlement mechanism of WTO accompanied by DSB-case approach approach in knowing how much involvement developed and developing countries in the WTO DSB forum and how far-WTO DSB role in resolving international commercial disputes. Based on the study it can be concluded that through the WTO dispute settlement mechanism has been set in the DSU agreement consisting of stages of consultation, the establishment of the panel and appellate body (Appellate Body), the adoption and implementation of the recommendation or decision of the appeal. the period 2001 to 2011 a number of consultation requests as a first step in the mechanism of DSB and shows increased partisispasi developing countries into the WTO DSB system. Within 8 years of the period 2001-2011, has been an increase in the involvement of developing countries in the WTO DSB-use agency that originally dominated by developed countries. While the role of the DSB-WTO has increased the number of cases handled.
\end{abstract}

Keywords: DSB-WTO trade dispute settlement mechanism, the role of DSB-WTO

\begin{abstract}
Abstrak
Semakin intensenya hubungan perdagangan internasional telah menimbulkan peningkatan ketegangan yang menimbulkan sengketa perdagangan antar bangsa, baik dalam perdagangan barang maupun jasa. Penelitian ini memfokuskan pada persoalan yang bersifat prosedural yakni bagaimana mekanisme penyelesaian sengketa melalui DSB-WTO, dan bagaimana keterlibatan negara maju dan negara berkembang dalam penyelesaian sengketa dagang internasional serta bagaimana peranan DSB WTO dalam penyelesaian sengketa. Penelitian ini menggunakan pendekatan statue approach dalam memngetahui mekanisme penyelesaian sengketa dagang melalui DSB-WTO diserta pendekatan case approach dalam mengetahui seberapa jauh keterlibatan negara maju maupun

${ }^{1}$ Penulis adalah Dosen Fakultas Hukum Unsoed, Ketua Bagian Hukum Internasional periode Tahun 2010-2014. Alamat kontak: ademamans@yahoo.com.
\end{abstract}


berkembang dalam pada forum DSB-WTO dan seberapa jauh peranan DSB WTO dalam penyelesaian sengketa dagang internasional. Berdasarkan penelitian dapat diambil kesimpulan bahwa mekanisme penyelesaian sengketa melalui WTO telah diatur dalam DSU agreement yang terdiri dari tahapan konsultasi, pembentukan panel dan lembaga banding (appellate Body), pengadopsian dan implementasi rekomendasi atau putusan banding. periode 2001 sampai 2011 sejumlah permohonan konsultasi sebagai langkah pertama dalam mekanisme DSB dan menunjukan peningkatan partisispasi negara berkembang kedalam sistem DSB WTO. Dalam waktu 8 tahun dari periode 2001-2011,Telah terjadi peningkatan keterlibatan negara berkembang dalam penggunaan lembaga DSBWTO yang semula didominasi negara-negara maju. Sedangkan peranan DSBWTO semakin mengalami peningkatan jumlah kasus yang ditangani.

Kata Kunci: DSB-WTO, makanisme Penyelesaian sengketa dagang dan Peranan DSB-WTO

\section{Pendahuluan}

Lembaga Penyelesaian Sengketa WTO yang selanjutnya disingkat LPSWTO telah menunjukan kontribusi dan peran yang signifikan dalam menyelesaikan sengketa perdagangan antar negara anggota. Dalam kurun waktu 15 tahun, LPS-WTO telah masuk ke WTO sehingga lembaga penyelesaian sengketa WTO menjadi suatu yang strategis dan penting dalam penyelesaian sengkjeta dagang internasional. Pecapaian tersebut benar-benar telah melampaui kinerja lembaga penyelsaian sengketa internasional lainnya seperti Mahkamah Internasional atau International Court of Justice yang hanya menerima sebanyak 150 perkara sejak lebih dari 65 tahun yang lalu. ${ }^{2}$ Demikian juga Mahkamah Internasional untuk Hukum laut (The International Tribunal for the Law of the Sea) yang didirikan tahun tahun 1996 atau dua tahun berikutnya setelah WTO didirikan telah memproses 15 kasus, bahkan Kamar untuk Persoalan Lingkungan yang didirikan oleh ICJ tahun 1993 yang akhirnya ditutup pada tahun 2006 tidak pernah menerima satu kasus sekalipun. ${ }^{3}$

\section{Perumusan masalah}

Berdasarkan latar belakang diatas, maka untukmengkaji peranan DSBWTO, maka dapat dirumuskan permasalahan sebagai berikut: Bagaimana prosedur penyelesaian sengketa melalui DSB-WTO, dan seberapa besar peranan

\footnotetext{
${ }^{2}$ Sebanyak 419 senhgketa telah diajukan antara bulan Januari 1994 sampai bulan Desember 2010, dan sebanyak 200 kasus telah memperoleh putusan final (in kracht).

3 Tahun 2010 merupakan tahun yang Istimewa untuk WTO dispute settlement, sebagaimana di release dalam peringatan tahun ke 15 sejak didirikannya sistem penyelesaian sengketa WTO.
} 
DSB - WTO dalam menyelesaiakan sengketa perdagangan internasional antar negara anggota WTO.

\section{Metode Penelitian}

Penelitian merupakan penelitian doktrinal yang meliputi pendekatan filosofisyang bersumber dari hukum alam, pendekatan positifistik (juris-legis) dan pendekatan historis-realisme. Penelitian ini menggunakan merupakan penelitian doktrinal positifistik dengan menggunakan pendekatan statute approach dan pendekatan kasus (case approach) dan dianaliss secara kualitatif untuk ditarik suatu konklusi dengan menggunakan metode deduktif. Penelitian tentang prosedur penyelesaian sengketa berdasarkan dispute settlement understanding yang mengacu pada ketentuan dalam WTO, serta seberapa jauh peranan DSB - WTO mempu menjadi suatu lembaga penyelesaian sengketa yang kredibel dan dipercaya oleh negara yang bersengketa. Penelitian didasarkan pada data sekunder yang terdiri atas bahan hukum primer dan bahan hukum sekunder serta bahan hukum tersier. Bahan hukum primer dapat berupa konvensi internasional, perjanjian internasional, dispute settlement body, act of international organisation dan hukum nasional sepanjang terkait dengan perdagangan internasional.

\section{Hasil Penelitian dan Pembahasan}

Sebagaimana ditegaskan oleh Yonov Frederick Agah $^{4}$ bahwa sistem penyelesaian sengketa oleh WTO sangat aktif dan efektif dalam penyelesaian sengketa. Pertanyaan mendasar jua apakah penyelesaian sengketa dilakukan secara cepat atau "prompt settlement". Dalam praktinya penyelesaian sengketa benar-benar telah menjadi sustu yang esensial dan berfungsi menjaga memelihara keseimbangan hak dan kewajiban para pihak yang bersengketa dari negara anggota. ${ }^{5}$ DSB -WTO telah menunjukan kinerja dan progres yang positif dan menjawab keraguan banyak kalangan bahwa proses penyelesaian sengketa dirasa terlalu lama. Sesungguhnya DSB menyelesaiakna suatu perkara jauh lebih cepat dibandingkan dengan forum-forum regional seperti ICJ, ECJ dan NAFTA. Ratarata time frame panel WTO adalah 10 bulan tidak termasuk waktu menyusun panel dan menerjemahkan laporan. Dibandingkan dengan ICJ adalah 4 tahun, ECJ dua tahun dan NAFTA dalam Chapter 20 mencapai 3 tahun dan 5 tahun. ${ }^{6}$ Selain lebih cepat dari lembaga penyelesaian sengketa di atas, prosiding settlemet

\footnotetext{
${ }^{4}$ Yonov Frederick Agah, Dispute Settlement: Analysis oleh Frederick Agah: WTO Dispute Settlement Body developments in 2010, served as Chairman of the Dispute Settlement Body from 19 March 2010 to 24 February 2011. Artikel ini dipublikasikan pada musim panas 2012 dalam suatu momen khusus tentang dispute settlement WTO untuk perdagangan, hukum dan pembangunan yang dipublikasikan oleh National Law University, Jodhpur, India.

${ }^{5}$ Article 3.3 of the DSU.

${ }^{6}$ Yonov Frederick Aaagah, Op. Cit., hal. 2.
} 
melalui WTO lebih cepat dari arbitrase antar negara atau investor-state arbitrations pada bank dunia atau World Bank's International Centre for the Settlement of Investment Disputes, yang lebih dikenal dengan ICSID. Arbitrase ICSID memerlukan rata-rata lebih dari 3,5 tahun per perkara. Suatu hal yang mengejutkan adalah diperlukan sekitar 14 bulan antara hearing terakhir sampai putusan ICSID.

Secara diagram, DSB WTO memperoleh mandat dari negara anggota, khususnya dari negara pemohon untuk melakukan pemeriksaan atas keberatan atau gugatan dari negara yang hak-hak nya dilanggar oleh negara anggota lainnya berdasarkan ketentuan WTO.

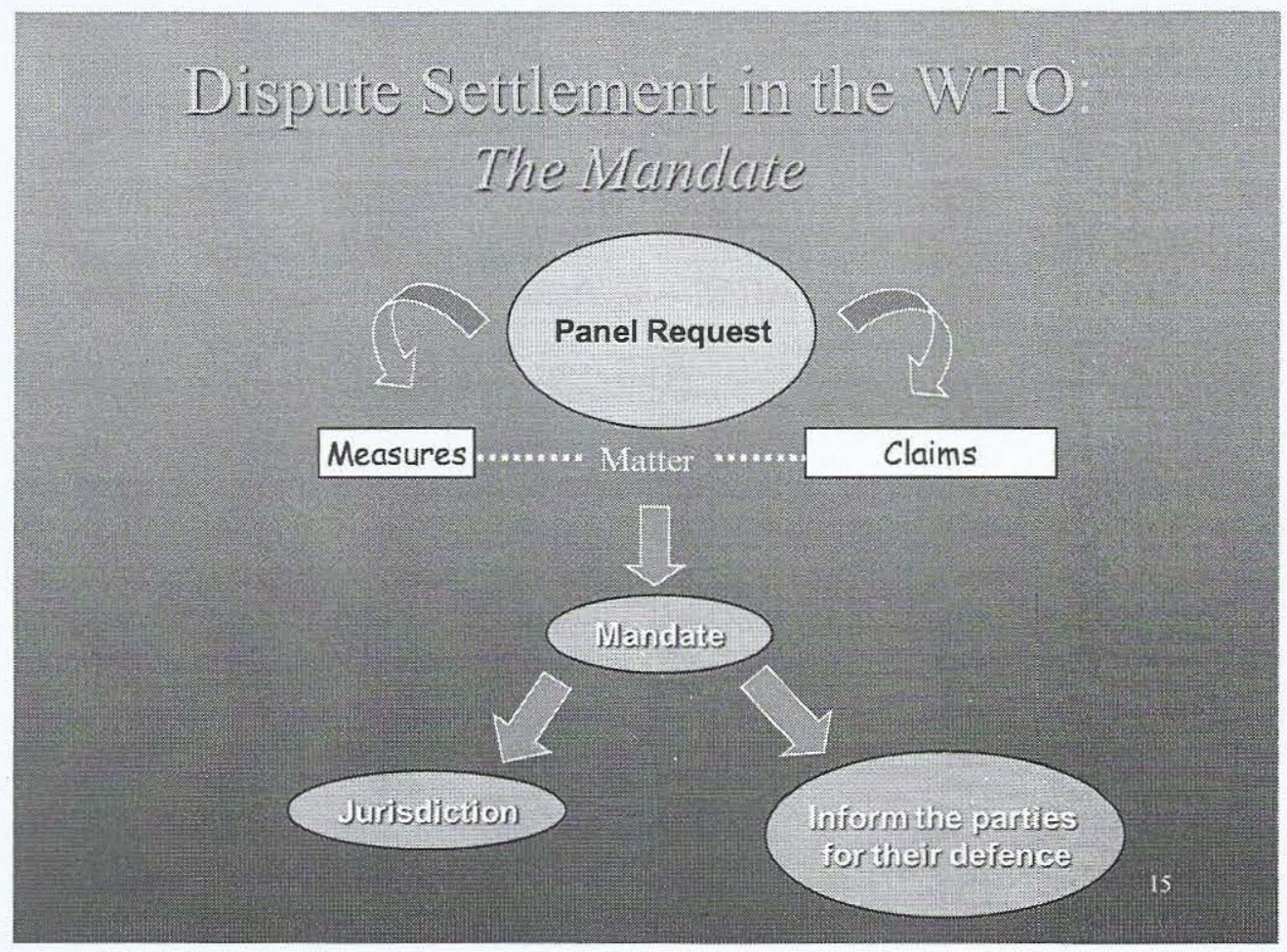

\section{Sengketa Dagangan Melalui LPS-WTO}

Sistem penyelesaian sengketa melalui LPS -WTO diatur dalam Understanding on Rules and Procedures Governing the settlement of dispute yang biasa disebut DSU. Substansi ketentuan yang ada dalam DSU merupakan interpretasi dan implementasi dari ketentuan Pasal IIII GATT 1947 dan badan yang melaksanakannya adalah Dispute Settlement Body atau DSB. Lembaga tersebut merupakan bagian dari Dewan Umum atau General Council WTO sehingga semua negara anggota terikat dan mempunyai hak yang sama untuk menggunakan eksistensi dari DSB tersebut.

Struktur DSU dalam perjanjian WTO adalah sebagaimana dijelaskan dalam bagan berikut ini: 


\section{Bagan 1 Struktur WTO}

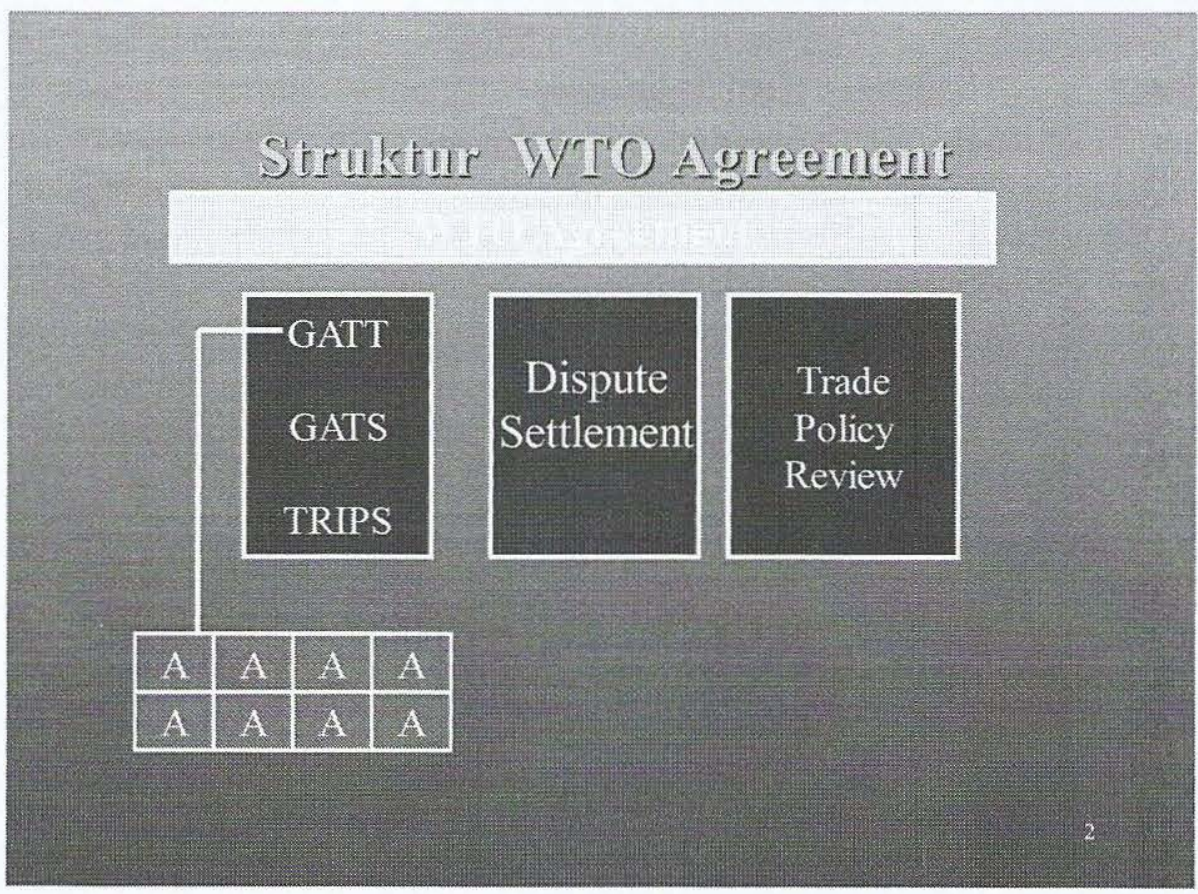

Mengenai kewenangan DSB meliputi membentuk Panel, mengadopsi Panel dan laporan Badan banding (appellate Body report), melaksanakan pengawasan implementasi terhadap rekomendasi dan keputusan yang telah dibuat serta mengotorisasi penundaan konsesi (suspension of concessions). Dengan adanya DSB, maka semeua anggota WTO wajib menyelesaiakan sengketa dagang melalui jalur ini dan semua negara anggota tidak diperbolehkan mengambil tindakan secara sepihak (unilateral) yang akan menimbulkan persoalan baru secara bilateral maupun multilateral.

Berdasarkan Pasal 3 DSU dapat diketahui tugas utama dari DSB adalah sebagai berikut:

a. Mengklarifikasi ketentuan-ketentuan yang ada dalam perjanjian WTO dengan melakukan interpretasi menurut hukum kebiasaan Internasional publik;

b. Hasil penyelesaian sengketa tidak boleh menambah atau mengurangi hakhak dan kewajiban yang diatur dalam ketentuan WTO;

c. Menjamin solusi yang positif dan diterima oleh para pihak dan konsisten dengan substansi perjanjian dalam WTO;

d. Memastikan penarikan tindakan negara pelanggar yang tidak sesuai dengan ketentuan-ketentuan perjanjian yang sudah tercakup dalam agreement (covered agreement). ${ }^{7}$ Tindakan retaliasi atau pemabalasan dimungkinkan tetapi sebagai upaya terakhir (last resort settlement).

${ }^{7}$ Covered agrement terdiri atas dua macam agreement: pertama adalah multulateral trade agreement yang meliputi: trade in goods, general agreement on trade in services, TRIPS, 
Putusan yang diambil oleh DSB harus dilakukan secara konsesnsus dimana mekanisme yang digunakan adalah reverse consensus atau negative consensus artinya DSB harus dianggap mengambil suatu putusan jika tidak ada konsensus untuk tidak mengambil mengambil putusan yang bersangkutan. Dengan kata lain pembentukan panel dan pengadopsian laporan panel dapat secara otomatis berjalan, kecuali ada penolakan dari seluruh anggota WTO. Konsensus negatif ini dipergunakan sebagai pengganti sistem yang lama yakni kensensus positif. Konsensus negatif ini ditujukan untuk mencegah terhambatnya proses penyelesaian sengketa apabila dikarenakan ada satu negara anggota yang menolak yang menimbulkan tidak dapat dilangsungkannya proses penyelesaian sengketa. Saat ini sepanjang satu anggota menghendaki untuk mengadopsi laporan, laporan tersebut otomatis akan diadopsi. Selanjutnya pihak yang kalah dan tidak puas dapat mengajukan banding, upaya hukum banding ini baru ada sejak berdirinya WTO dimana sebelumnya dalam era GATT tidak dikenal upaya hukum banding. Hukum acara dalam penyelesaian sengketa di DSB melalui sejumlah tahapan yaitu: Konsultasi, Proses Panel, Proses bandingB, Adopsi dan Pengawasan Implementasi.

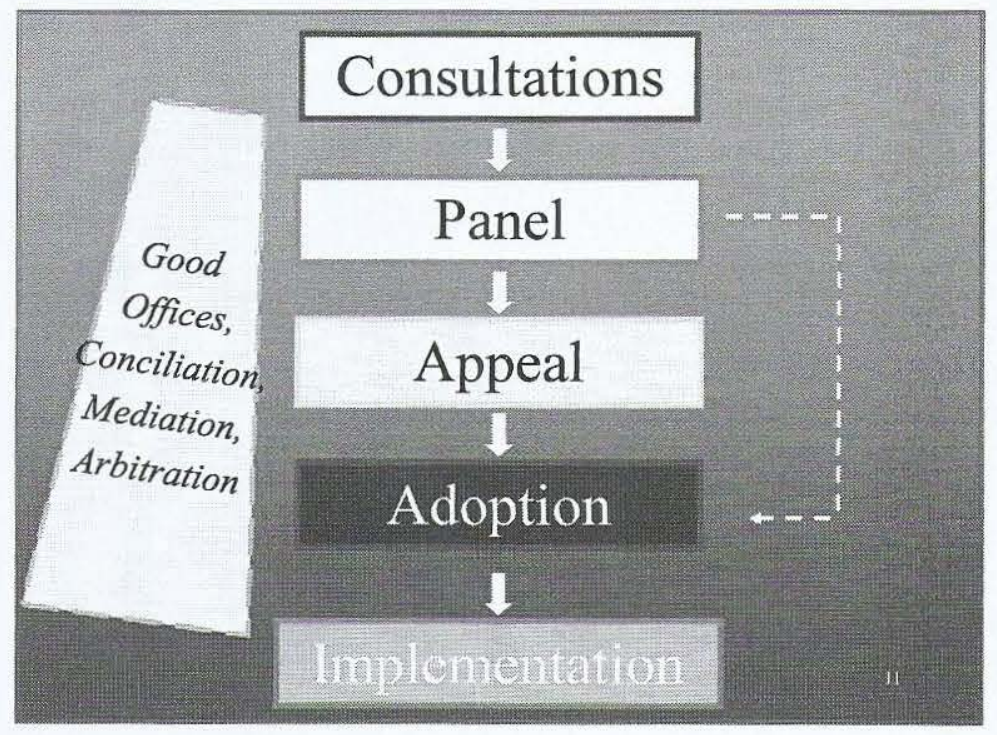

\section{Konsultasi}

Langkah pertama dari prosedur penyelesaian sengketa WTO adalah consultasi.Konsultasi ini merupakan permintaan negara anggota yang dituduh melanggar ketentuan WTO atau berakibat meniadakan atau menghambat keuntungan negaranya. Negara pelanggar harus merespon permintaan tersebut dalam jangka waktu 10 hari, dan harus sudah mulai melaksanakan dalam waktu 30 hari sejak permohonan konsultasi diajukan,

Understanding on Rules and procedures governing thew settlement Dispute. Kedua adalah Plurilateral trade agreement yang meliputi: trade in Civil Aircraft, agreement on Government procurement, international Dairy Agreement dan International Bovine Agreement. 
dan harus diselesaikan dalam jangka waktu 60 hari sejak permohonan konsultasi diajukan (Pasal 4.3 dan 4.7 DSU). ${ }^{8}$

Bagaimana dengan sengketa dagang yang objek perdagangan tersebut merupakan barang-barang yang mudah rusak atau hancur (perishable goods). Kebanyakan produk yang berasal dari negara berkembang memiliki karakteristik yang mudah rusak. Apakah tetap menggunakan tenggat waktu (time frame) sebagaimana diuraikan diatas. Ketentuan mengenai perishable goods dan penanganan sengketa di WTO harus memperhatikan aspek-aspek khusus dan kepentingan negara berkembang. Hal tersebut diatur dalam Pasal 5, angka 8.9 dan 10 DSU. Dalam kondisi urgent, maka tenggang waktu permohonan harus sudah direspon tidak lebih dari 10 hari dan apabila dalam waktu 20 hari belum tercapai kesepakatan, maka negara pemohon dapat mengusulkan pembentukan panel.

Konsultasi ini dilakukan dengan tujuan, pertama adalah untuk memberikan pemahaman awal para pihak atas kondisi faktual dan dasardasar hukum yang akan diajukan secara lebih mendalam dan tepat, kedua mengupayakan agar tidak melanjutkan sengketa pada tahap selanjutnya. Pada tahap ini terbuka peluang untuk melibatkan mekanisme penyelsaian sengketa secara damai dengan metode good offices, mediation, conciliation dan arbitration sebagai diatur dalam Pasal 5 DSU. ${ }^{9}$

Good offices (peran jasa baik), konsiliasi dan mediasi adalah merupakan prosedur yang ditempuh secara sukarela dengan sayarat para pihak sepakat melakukan langkah tersebut, pada ketentuan selanjutnya bahwa langkah yang diambil harus dijaga kerahasiaannya dan tanpa prejudice terhadap hakhak para pihak. Good offices, conciliation atau mediation dapat diajukan kapan saja oleh pihak manapun dalam sengketa, demikian juga dapat dimulai dan diakhiri kapan saja. Ketika prosedur tersebut sudah diakhiri dan negara pemohon atau complaining state dapat mengajukan permintaan pembentukan panel. ${ }^{10}$ Bagaimana jika dalam waktu 60 hari untuk konsultasi

${ }^{8}$ Article 4 Consultations angka 3. If a request for consultations is made pursuant to a covered agreement, the Member to which the request is made shall, unless otherwise mutually agreed, reply to the request within 10 days after the date of its receipt and shall enter into consultations in good faith within a period of no more than 30 days after the date of receipt of the request, with a view to reaching a mutually satisfactory solution. If the Member does not respond within 10 days after the date of receipt of the request, or does not enter into consultations within a period of no more than 30 days, or a period otherwise mutually agreed, after the date of receipt of the request, then the Member that requested the holding of consultations may proceed directly to request the establishment of a panel. Angka 7. If the consultations fail to settle a dispute within 60 days after the date of receipt of the request for consultations, the complaining party may request the establishment of a panel. The complaining party may request a panel during the 60-day period if the consulting parties jointly consider that consultations have failed to settle the dispute.

${ }^{9}$ Article 5 : Good Offices, Conciliation and Mediation

1. Good offices, conciliation and mediation are procedures that are undertaken voluntarily if the parties to the dispute so agree.

${ }^{10}$ Artikel 5.2 dan 5.3 DSU. 
tidak tercapai kesepakatan, maka negara pemohon harus mengijinkan adanya permohonan pembentukan panel diawal penyelesaian konsultasi, yang artinya diperjanjikan diawal bahwa apabila dalam waktu 60 hari tidak tercapai kesepakatan, maka sekaligus dapat dilanjutkan pembentukan panel. ${ }^{11}$ Pada tahap konsultasi, Dirjen WTO dapat bertindak sebagai ex officio capacity, sebagai good offices, conciliation atau mediation dan memberikan pandangan untuk membantu negara anggota.

\section{Pembentukan Panel}

Setelah konsultasi gagal untuk menyelesaiakan sengketa, maka langkah berikutnya adalah negara pemohon (complaining state) mengajukan permohonan pembentukan panel. Berdasarkan Pasal 6 angka 1 dan 2 disebutkan bahwa jika negara pemohon mengajukan pembentukan panel maka panel harus dibentuk pada pertemuaan DSB sejak permohonan pertama kali diajukan kecuali DSB sudah memutuskan secara konsensus untuk tidak membentuk panel. Panel akan dibentuk kira-kira 90 hari sejak permohonan konsultasi diajukan. Komposisi pembentukan panel harus diisi oleh pakar-pakar atau individi yang kualified baik yang berasal dari pemerintahan atau nonpemerintah sebagaimana diatur dalam Pasal 8 angka 1. ${ }^{12}$ Syarat lainnya untuk diangkat sebagai panelist WTO adalah independen, memiliki back gorund yang berbeda dan memiliki spektrum pengalaman yang luas. Panel members should be selected with a view to ensuring the independence of the members, a sufficiently diverse background and a wide spectrum of experience.

Setelah panel terbentuk oleh DSB kemudian dipilih 3 orang panelis dari sejumlah nama yang dinominasikan oleh sekretariat WTO. Jika dalam waktu 20 hari terjadi kebuntuan dalam penentuan panelis, maka masingmasing pihak dapat meminta Dirjend WTO untuk menunjuk panelis dan harus dilakukan dalam waktu 10 hari sejak permohonan tersebut. ${ }^{13}$ Apabila telah terpilih panelist secara definitif, mereka anggota panelis berpedoman pada ToR (term of referrence) yang tertuang dalam DSU uang berbunyi

${ }^{11}$ Artikel 5.4 DSU. When good offices, conciliation or mediation are entered into within 60 days after the date of receipt of a request for consultations, the complaining party must allow a period of 60 days after the date of receipt of the request for consultations before requesting the establishment of a panel. The complaining party may request the establishment of a panel during the 60-day period if the parties to the dispute jointly consider that the good offices, conciliation or mediation process has failed to settle the dispute.

12 Panels shall be composed of well-qualified governmental and/or non-governmental individuals, including persons who have served on or presented a case to a panel, served as a representative of a Member or of a contracting party to GATT 1947 or as a representative to the Council or Committee of any covered agreement or its predecessor agreement, or in the Secretariat, taught or published on international trade law or policy, or served as a senior trade policy official of a Member.

${ }^{13}$ Pasal 8 angka 7 DSU. 
sebagai berikut: ${ }^{14}$ Panel harus menggunakan ToR terhadap suatu sengketa kecuali negara penggugat tidak setuju dapat mengajukan bersamaan pembentukan panel (tetapi jarang terjadi). Adapun ToR yang dimaksud adalah sebagai berikut:

To examine, in the light of the relevant provisions in (name of the covered agreement(s) cited by the parties to the dispute), the matter referred to the DSB by (name of party) in document ... and to make such findings as will assist the DSB in making the recommendations or in giving the rulings provided for in that/those agreement(s).

Tugas panel melakukan penilaian secara objektif terhadap pokok permasalahan yang diajukan termasuk penilaian objektif terhadap faktafakta serta penerapan dan keseuaiannya dengan ketentuan perjanjian dalam WTO yang relevan. Fungsi Panel adalah membantu DSB berdasarkan tanggungjawabnya sesuai dengan Covered Agreement, melakukan asesmen yang objektif (objective assessment) dari pokok perkara termasuk asesmen objektif terhadap fakta-fakta dari kasus yang diajukan dan mencermati komformitas serta relevansi dengan covered agreements, serta membuat suatu temuan yang akan membantu DSB dalam membuat rekomendasi atau menerapkan aturan-aturan yang disyaratkan oleh covered agreement. Panel harus berkonsultasi secara reguler dengan para pihak dan memberikan mereka peluang yang tepat untuk mengembangkan suatu solusi yang saling memuaskan para pihak (mutually satisfactory solution).

Rekomendasi panel biasanya menyatakan tindakan yang bertentangan dengan aturan-aturan WTO tersebut agar disesuaikan. Panel dapat memberikan saran bagaimana menimplementasikan rekomendasi tersebut, namun pada umumnya tidak terjadi. Final Report harus sudah disampaikan kepada para pihak dalam jangka waktu enam bulan setelah penyusunan panel dan harus diedarkan kepada semua negara anggota WTO selambatlambatnya sembilan bulan setelah pembentukan panel. Praktiknya, final report akan memakan waktu selama satu tahun (12 bulan) dan semua negara anggota diberi waktu 20 hari untuk mempelajari selanjutnya laporan diserahkan kepada DSB untuk diadopsi secara formal dalam jangka waktu 60 hari sejak diedarkan, kecuali terdapat konsensus untuk tidak mengadopsinya atau terdapat banding. ${ }^{15}$ Untuk memperoleh waktu yang cukup anggota mempertimbangkan panel reports sampai 20 hari setelah diedarkan, ${ }^{16}$ apabila ada anggota keberatan terhadap panel report dapat

\footnotetext{
${ }^{14}$ Pasal 7.1 dan 6. 2 DSU.

${ }^{15}$ Pasal 15.2, 16.1, 16.4 DSU.

${ }^{16}$ Pasal 15.1 DSU.
} 
memberikan alasan tertulis untuk menerangkan keberatannya paling lambat 10 hari sebelum pertemuan DSB dilaksanakan. ${ }^{17}$

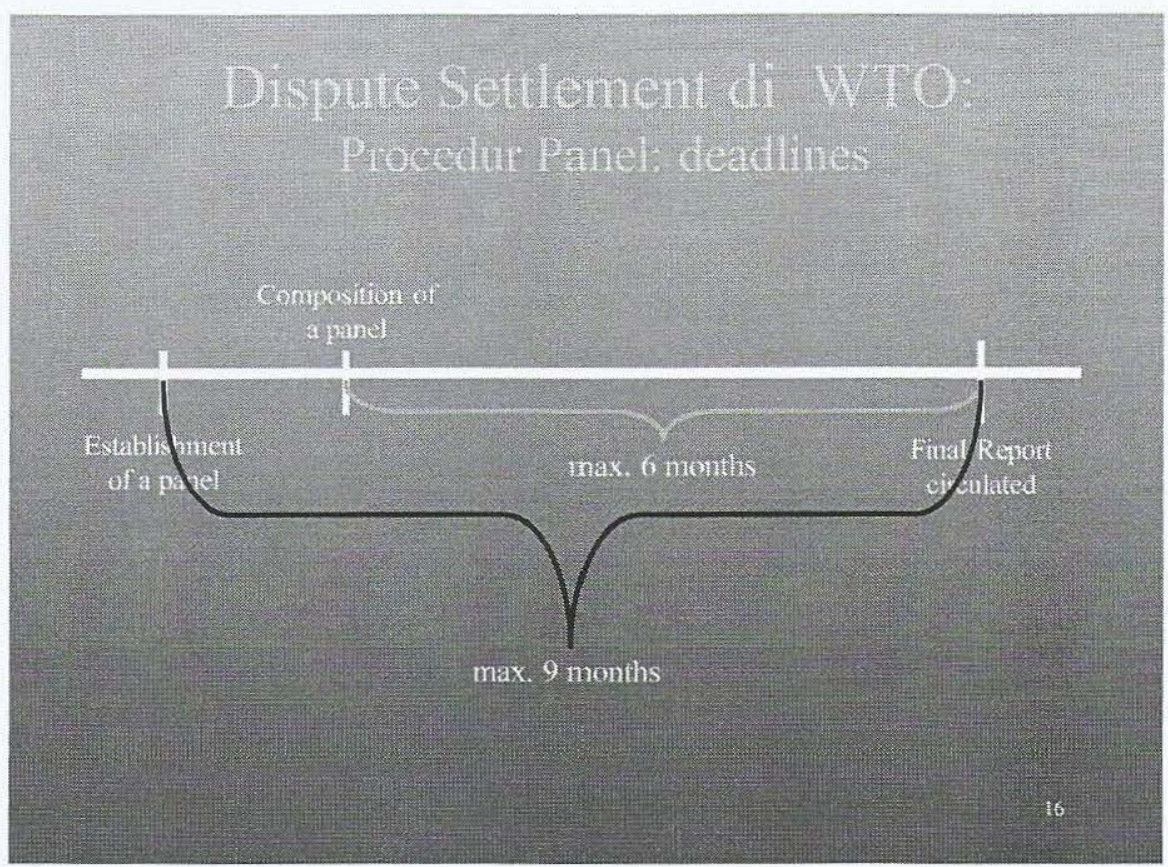

\section{Lembaga Banding WTO (Appellate Body)}

Anggota banding WTO terdiri atas para pakar dibidang hukum perdagangan internasional, tidak terafiliasi dengan pemerintah tertentu. Selain itu aspek keterwakilan dari keanggotaan WTO yang secara geografis mewakili region masing-masing yaitu Amerika, Amerika Selatan, Asia, Afrika Utara dan Afrika Selatan, dan secara peta dapat digambarkan sebagai berikut: ${ }^{18}$

${ }^{17}$ Pasal 16.2.

${ }^{18}$ Pasal 17 angka 3 DSU-WTO: The Appellate Body shall comprise persons of recognized authority, with demonstrated expertise in law, international trade and the subject matter of the covered agreements generally. They shall be unaffiliated with any government. The Appellate Body membership shall be broadly representative of membership in the WTO. All persons serving on the Appellate Body shall be available at all times and on short notice, and shall stay abreast of dispute settlement activities and other relevant activities of the WTO. They shall not participate in the consideration of any disputes that would create a direct or indirect conflict of interest. 


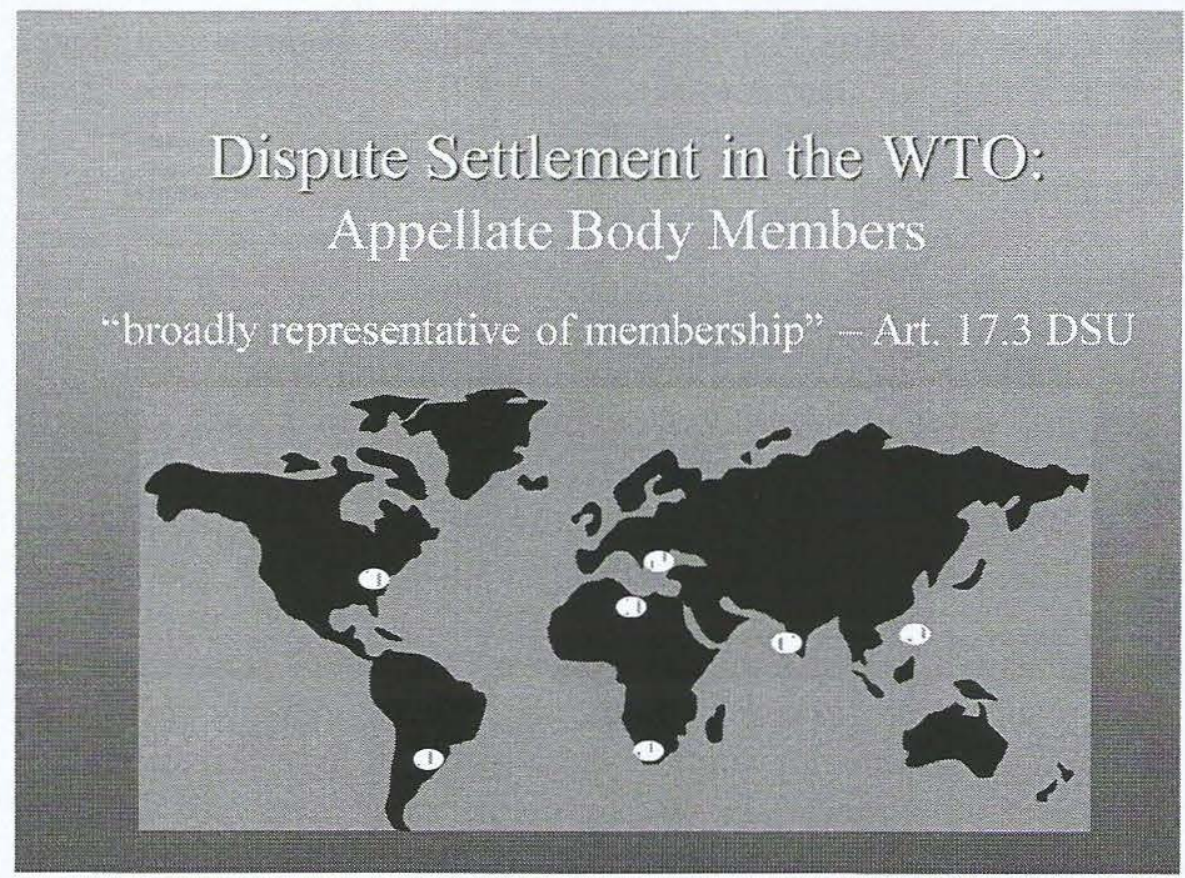

Anggota Banding (Applellate Review) terdiri atas tujuh orang yang dibentuk DSB. Appellate body harus memeriksa banding dari panel, appellate body terdiri atas tujuh orang. Setiap kasus ditangani oleh tiga anggota badan banding. Sebelum finalisasi putusan dari tiga anggota dianjurkan bertukarpikiran dengan empat anggota lainnya. ${ }^{19}$ Keanggotaan $\mathrm{AB}$ adalah selama empat tahun dan setiap anggota dapat dipilih kembali satu kali.

Prosedur operasional banding harus dirumuskan oleh $\mathrm{AB}$ dan berkonsultasi dengan ketua DSB dan Direktur Jenderal WTO serta dikomunikasikan dengan para anggota ${ }^{20}$, prosiding dan semuamdokumen $\mathrm{AB}$ bersifat rahasia atau confidential. Laporan $\mathrm{AB}$ harus di draft tanpa kehadiran para pihak yang bersengketa baik semua informasi dan pernyataan yang dibuat. ${ }^{21}$ Pendapat atau pandangan yang dituangkan dalam laporan $\mathrm{AB}$ oleh individu sebagai anggota $\mathrm{AB}$ harus bersifat anonymous. ${ }^{22}$ Adpun kewenangan dari $\mathrm{AB}$ adalah menegakan/menguatkan, merubah atau membalikan penemuan hukum dan kesimpulan yang telah dibuat oleh

19 Pasal 17 angka 1. DSU disebutkan bahwa: A standing Appellate Body shall be established by the DSB. The Appellate Body shall hear appeals from panel cases. It shall be composed of seven persons, three of whom shall serve on any one case. Persons serving on the Appellate Body shall serve in rotation. Such rotation shall be determined in the working procedures of the Appellate Body.

\footnotetext{
${ }^{20}$ Ibid., angka 9 DSU.

${ }^{21}$ Ibid., angka 10 DSU.

${ }^{22}$ Ibid, angka 11.
} 
panel. ${ }^{23}$ Laporan AB harus diadopsi oleh DSB dan diakseptasi tanpa syarat oleh para pihak yang bersengketa, kecuali DSB dengan konsensus tidak mau mengadopsi laporan $\mathrm{AB}$ dalam waktu 30 hari untuk diedarkan kepada anggota dan anggota akan memberikan pandangannya terhadap laporan AB.

\section{Rekomendasi Panel dan Appellate Body}

Berdsarkan Pasal 19 bahwa baik panel mau appellate Body menyimpulkan bahwa suatu ketentuan bertentangan dengan ketentuan WTO atau Covered Agreement, maka panel maupun AB harus merekomendasikan negara anggota yang bersengketa mendudukan aturan tersebut sejalan dengan agreement, juga rekomendasi panel maupun $\mathrm{AB}$ dapat menyarankan cara-cara terhadap negara yang bersengketa mengimplementasikan rekomendasinya. ${ }^{24}$ Berdasarkan paragrap 2 artikel 3 bahwa penemuan dan rekomendasi baik panel maupun $\mathrm{AB}$ tidak dapat menambah atau mengurangi hak dan kewajiban yang diatur dalam Covered Agreement. Time frame atau rancangan waktu untuk panel dan $\mathrm{AB}$ adalah 9 bulan apabila panel tidak dilakukan banding, dan 12 bulan apabila panel harus dilanjutkan ke tahapan banding. ${ }^{25}$

\section{Pengawasan Implementasi (Surveillance of implementation)}

Tahapan akhir dari rangkaian penyelesaian sengketa melalui DSB adalah pengawasan implementasi dari rekomendasi yang telah dilakukan oleh panel maupun AB. Pengawasan ini merupakan tahapan untuk memastikan apakah laporan atau rekomendasi dari panel atau $\mathrm{AB}$ dilaksanakan atau tidak oleh para pihak. Norma yang umum diterapkan adalah apabila negara pelanggar direkomendasikan untuk menyesuaikan tindakannya agar sesuai dengan kewajiban-kewajiban yang diatur dalam ketentuan WTO.

Pasal 21 angka 1 menegaskan betapa pentingnya ketaatan dan kepatuhan menjalankan laporan atau rekomendasi Panel maupun AB demi efektifnya pengawasan dan implementasi ketentuan DSU. Pemenuhan seketika atas rekomendasi atau aturan dari DSB merupakan hal penting agar

${ }^{23}$ Ibid, angka 13.

${ }^{24}$ Pasal 19 DSU.

${ }^{25}$ Pasal 20 DSU Article 20 Time-frame for DSB Decisions

Unless otherwise agreed to by the parties to the dispute, the period from the date of establishment of the panel by the DSB until the date the DSB considers the panel or appellate report for adoption shall as a general rule not exceed nine months where the panel report is not appealed or 12 months where the report is appealed. Where either the panel or the Appellate Body has acted, pursuant to paragraph 9 of Article 12 or paragraph 5 of Article 17, to extend the time for providing its report, the additional time taken shall be added to the above periods. 
terjaminnya resolusi yang efektif dari suatu sengketa untuk kemanfaatan semua negara anggota. Fungsi pengawasn akan berjalan ketika negara pelanggar diwajibakan melaksanakan rekomendasi DSB dalam jangka waktu 30 hari sejak pengadopsian oleh DSB, dan apabila jangka waktu tersebut tidak memungkinkan, negara tersebut diperbolehkan untuk meminta jangka waktu pelaksanaan yang wajar (reasonable period of time) dengan syarat tidak melebihi 15 bulan. ${ }^{26}$ Tahap pengawasan khususnya untuk negara berkembang tetap diperlukan perhatian khusus terhadap halhal yang mempengaruhi kepentingan negara berkembang berkaitan dengan ketentuan yang ada relevansinya dengan penyelesaian sengketa. Pertemuan DSB dilaksanakan paling lambat 30 hari sejak tanggal pengadopsian laporan atau rekomendasi panel atau $\mathrm{AB}$, anggota yang terkait dengan sengketa harus menginformasikan niatnya untuk implementasi recommendasi DSB. Jika tidak dapat dilaksanakan secara segera, negara yang anggota dapat mengajukan periode waktu yang reasonable. Waktu yang reasonable harus memenuhi syarat sebagai berikut:

(a) periode waktu yang diajukan negara berperkara dimana hal tersebut disetujui oleh DSB;

(b) periode waktu secara mutual disetujui para pihak yang berperkara dalam jangka waktu 45 hari setelah tanggal pengadopsian rekomendasi maupun rulings. atau ketidak adaan persetujuan (in the absence of approval);

(c) periode waktu ditentukan melalui arbitrase yang mengikat dalam waktu 90 hari setelah tanggal pengadopsian rekomendasi atau rulings. $^{27}$ dalam arbitrase pedoman untuk arbitrator harus menentukan periode waktu yang masuk akal untuk mengimplementasikan rekomendasi panel maupun appellate body namun tidak boleh melebihi dari 15 bulan sejak tanggal pengadopsian laporan panel atau appellate body. Bagaimanapun waktunya dapat lebih singkat atau lebih lama tergantung kondisi tertentu.

Permasalahan mendasar adalah bagaimana apabila Laporan atau Rekomwendasi Panel atau appellate Body tidak dipatuhi noleh negara termohon (non executable). Apakah dimungkinkan adanya tindakan pembalasan oleh negara pemohon atau posibility of retaliatory. Sebagai contoh tentang kasus Kertas (paper case) dimana kasus ini diajukan oleh Indonesia, dimana Kanada, Cina dan Masyarakat Eropa sebagai pihak ketiga menggugat Korea. Pada tangal 28 November 2005 DSB mengadopsi laporan panel dengan judul resmi Korea-Antidumping Duties on Imports of

${ }^{26}$ Pasal 21.3 dan 21.4 DSU.

${ }^{27}$ If the parties cannot agree on an arbitrator within ten days after referring the matter to arbitration, the arbitrator shall be appointed by the Director-General within ten days, after consulting the parties. 
Certain paper from Indonesia (official Case WTO/312). ${ }^{28}$ Korea Versus Indonesia tentang kasus kertas telah di release melalui perkara Korea Certain Paper Panel Report, Korea - Anti-Dumping Duties on Imports of Certain Paper from Indonesia, WT/DS312/R, adopted 28 November 2005, DSR 2005:XXII, 10637. Selanjutnya, dua tahun kemudian DSB mengeluarkan agenda perkara yaitu Korea - Certain Paper (Article 21.5 Indonesia) Panel Report, Korea - Anti-Dumping Duties on Imports of Certain Paper from Indonesia - Recourse to Article 21.5 of the DSU by Indonesia, WT/DS312/RW, adopted 22 October 2007, DSR 2007:VIII, 3369. Disamping dua kasus kertas dengan Indonesia, Korea digugat sebagai negara yang melakukan pelanggaran terhadap ketentuan WTO, diantaranya adalah kasus-kasus sebagai berikut:

(1). Korea - Alcoholic Beverages Appellate Body Report, Korea Taxes on Alcoholic Beverages, WT/DS75/AB/R, WT/DS84/AB/R, adopted 17 February 1999, DSR 1999:I, 3

(2). Korea - Alcoholic Beverages Panel Report, Korea - Taxes on Alcoholic Beverages, WT/DS75/R, WT/DS84/R, adopted 17 February 1999, as modified by Appellate Body Report WT/DS75/AB/R, WT/DS84/AB/R, DSR 1999:I, 44

(3). Korea - Alcoholic Beverages (Article 21.3(c)) Award of the Arbitrator, Korea - Taxes on Alcoholic Beverages - Arbitration under Article 21.3(c) of the DSU, WT/DS75/16, WT/DS84/14, 4 June 1999, DSR 1999:II, 937

(4). Korea - Certain Paper Panel Report, Korea - Anti-Dumping Duties on Imports of Certain Paper from Indonesia, WT/DS312/R, adopted 28 November 2005, DSR 2005:XXII, 10637

(5). Korea - Certain Paper (Article 21.5 - Indonesia) Panel Report, Korea - Anti-Dumping Duties on Imports of Certain Paper from Indonesia - Recourse to Article 21.5 of the DSU by Indonesia, WT/DS312/RW, adopted 22 October 2007, DSR 2007:VIII, 3369

(6). Korea - Commercial Vessels Panel Report, Korea - Measures Affecting Trade in Commercial Vessels, WT/DS273/R, adopted 11 April 2005, DSR 2005:VII, 2749

(7). Korea - Dairy Appellate Body Report, Korea - Definitive Safeguard Measure on Imports of Certain Dairy Products, WT/DS98/AB/R, adopted 12 January 2000, DSR 2000:I, 3

(8). Korea - Dairy Panel Report, Korea - Definitive Safeguard Measure on Imports of Certain Dairy Products, WT/DS98/R and Corr.1, adopted 12 January 2000, as modified by Appellate Body Report WT/DS98/AB/R, DSR 2000:I, 49

${ }^{28}$ Korea termasuk negara yang digugat sejumlah negara karena praktik dagang yang melanggar ketentuan WTO. 
(9). Korea - Procurement Panel Report, Korea - Measures Affecting Government Procurement, WT/DS163/R, adopted 19 June 2000, DSR 2000:VIII, 3541

(10). Korea - Various Measures on Beef Appellate Body Report, Korea - Measures Affecting Imports of Fresh, Chilled and Frozen Beef, WT/DS161/AB/R, WT/DS169/AB/R, adopted 10 January 2001, DSR 2001:I, 5

(11). Korea - Various Measures on Beef Panel Report, Korea Measures Affecting Imports of Fresh, Chilled and Frozen Beef, WT/DS161/R, WT/DS169/R, adopted 10 January 2001, as modified by Appellate Body Report WT/DS161/AB/R, WT/DS169/AB/R, DSR 2001:I, 59

Berdasarkan artikel 22 DSU, kompensasi dan penanggughan konsesi atau kewajiban lainnya adalah merupakan tindakan temporer ketika rekomendasi atau rulings tidak diimplementasikan dalam periode waktu yang reasonable. ${ }^{29}$ Berdasarkan Pasal 22 angka 3, dalam mempertimbangkan penangguhan konsesi atau kewajiban lain, negara penggugat harus menerapkan prinsip dan prosedur sebagai berikut diantaranya adalah:

(a) Prinsip umum bahwa negara penggugat pertama harus mencari penangguhan konsesi atau kewajiban lainnya yang berkaitan dengan sektor yang sama sebagaimana panel atau AB telah menetapkan suatu pelanggaran atau nulifikasi atau impairment.

(b) Apabila poin a tidak praktis atau dapat diterapkan, atau tidak efektif menangguhkan konsesi atau kewajiban lain pada sektor yang sama maka dapat mencari penangguhan konsesi atau kewajiban yang lain pada sektor lain atau yang berbeda berdasarkan satu perjanjian yang sama;

(c) Jika poin a dan $\mathrm{b}$ tidak memungkinkan diterapkan, maka penangguhan konsesi dan kewajiban lain berdasarkan cover agreement yang berbeda.

${ }^{29}$ Compensation and the suspension of concessions or other obligations are temporary measures available in the event that the recommendations and rulings are not implemented within a reasonable period of time. However, neither compensation nor the suspension of concessions or other obligations is preferred to full implementation of a recommendation to bring a measure into conformity with the covered agreements. Compensation is voluntary and, if granted, shall be consistent with the covered agreements. 
Tabel 1.

Aturan Tambahan Khusus dan Prosedur dalam Covered Agreement

\begin{tabular}{|l|l|}
\hline \multicolumn{1}{|c|}{$\begin{array}{c}\text { Aturan Perjanjian dan } \\
\text { Prosedur }\end{array}$} & \multicolumn{1}{c|}{ Pasal } \\
\hline $\begin{array}{l}\text { Agreement on the Application of } \\
\text { Sanitary and Phytosanitary } \\
\text { Measures }\end{array}$ & 11.2 \\
\hline $\begin{array}{l}\text { Agreement on Textiles and } \\
\text { Clothing }\end{array}$ & $2.14,2.21,4.4,5.2,5.4,5.6,6.9$. \\
\hline $\begin{array}{l}\text { Agreement on Technical } \\
\text { Barriers to Trade }\end{array}$ & 14.2 sampai 14.4, Annex 2 \\
\hline $\begin{array}{l}\text { Agreement on Textiles and } \\
\text { Clothing }\end{array}$ & $\begin{array}{l}2.14,2.21,4.4,5.2,5.4,5.6,6.9, \\
6.10,6.11,8.1 \text { sampai } 8.12\end{array}$ \\
\hline $\begin{array}{l}\text { Agreement on Implementation } \\
\text { of Article VI of GATT 1994 }\end{array}$ & 17.4 through 17.7 \\
\hline $\begin{array}{l}\text { Agreement on Implementation } \\
\text { of Article VII of GATT 1994 }\end{array}$ & $\begin{array}{l}19.3 \text { through 19.5, Annex II.2(f), 3, } \\
9,21\end{array}$ \\
\hline $\begin{array}{l}\text { Agreement on Subsidies and } \\
\text { Countervailing Measures }\end{array}$ & $\begin{array}{l}4.2 \text { through 4.12, 6.6, 7.2 through } \\
7.10,8.5, \text { Footnote 35, 24-4, 27-7 } \\
\text { annex V }\end{array}$ \\
\hline $\begin{array}{l}\text { General agreement on trade and } \\
\text { services }\end{array}$ & XXII-3- XXIII-3 \\
\hline annex on financial services & IV \\
\hline annex on air transport services & $I V$ \\
\hline $\begin{array}{l}\text { Decision on certain Dispute } \\
\text { Settlement }\end{array}$ & Prosedur GATA 1 sampai 5 \\
\hline
\end{tabular}

Prosedur kerja dalam menyelenggarakan sidang dituntut adanya transparansi dan standar yang telah ditentukan. Untuk kepentingan hal tersebut telah dirumuskan working prosedur sebagai berikut: bahwa panel berhak memanggil para pihak dsan pihak ketiga dan mengajukan pertanyaan kepadanya baik dalam pertemuan dengan para pihak atau dalam pertanyaan bentuk tertulis. ${ }^{30}$ Para pihak yang bersengketa dan pihak ketiga diundang untuk menyampaikan pandangannyaberdasarkan artikel 10 harus siap dihadapan panel dalam versi tertulis dari statement lisan yang disampaikan. ${ }^{31}$ Demi kepentingan transparansi, presentasi, perdebatan, bantahan dan pernyataan mengacu pada paragrap 5 sampai dengan 9 harus dihadiri para pihak. Maka pengajuan tertulis dari para pihak termasuk

\footnotetext{
${ }^{30}$ Angka 8 .

${ }^{31}$ Ibid., angka 9.
} 
komentar deskriptif dari laporan atau respon yang disampaikan panel harus tersedia untuk pihak lain atau para pihak yang bersengketa. ${ }^{32}$

Sebagai bentuk kepastian dan ketertiban penyelesaian sengketa, maka dibuat timetable untuk pedoman panel dalam melaksanakan tugasnya sebagai berikut:

a. Permintaan permohonan tertulis para pihak:

1) Pihak Penggugat: $3 \mathrm{~s} / \mathrm{d} 6 \mathrm{minggu}$;

2) Pihak Tergugat: 2 s/d 3 minggu.

b. Tanggal, waktu dan tempat untuk pertemuan substantif pertama:

Dengan para pihak; sesi pihak ketiga: $1 \mathrm{~s} / \mathrm{d} 2$ minggu

c. Penerimaan bantahan para pihak: $2 \mathrm{~s} / \mathrm{d} 3$ minggu

d. Tanggal, waktu dan tempat pertemuan substantif kedua: 1 s/d 2 minggu;

e. Penerbitan deskripsi bagian dari laporan kepada para pihak: 2 s/d 4 minggu;

f. menerima komentar oleh para pihak: 2 minggu;

g. laporan sementara termasuk temuan/kesimpulan untuk para pihak: 2 s/d 4 minggu;

h. Deadline para pihak untuk memohon review laporan: 1 minggu;

i. Periode review oleh panel, termasuk tambahan meeting dengan para pihak: 2 minggu;

j. Pengajuan laporan akhir terhadap para pihak: 2 minggu;

k. Sirkulasi laporan akhir kepada para anggota: 3 minggu.

Aplikasi kongkrit kasus penyelesaian sengketa melalui WTO dapat dilihat dari kasus Indonesia versus Korea Selatan sebagai berikut:

Tabel 2. Sengketa Dagang Indonesia versus Korea

\begin{tabular}{|l|l|}
\hline Tahapan/Waktu & \multicolumn{1}{c|}{ Agenda } \\
\hline Konsultasi, 7 Juli 2004 & $\begin{array}{l}\text { Membahas tentang data yang selayaknya } \\
\text { digunakan sebagai dasar tuduhan praktik } \\
\text { dumping }\end{array}$ \\
\hline Panel 16 Agustus 2004 & Indonesia Meminta pembentukan \\
\hline $\begin{array}{l}\text { Panel I 1-2 Februari } \\
\text { 2005 }\end{array}$ & $\begin{array}{l}\text { Membahas besaran margin dumping dan } \\
\text { penentuan kerugian(injury) dari produk yang } \\
\text { disengketakan }\end{array}$ \\
\hline Panel II 30 maret 2005 & $\begin{array}{l}\text { Indonesia dan korea membahas tentang definisi } \\
\text { dari barang sejenis (like product) sebagai } \\
\text { barang yang disengketakan serta mendengarkan } \\
\text { pihak ketiga (hearing) }\end{array}$ \\
\hline $\begin{array}{l}\text { Putusan panel 28 } \\
\text { Oktober 2005 }\end{array}$ & $\begin{array}{l}\text { Panel DSB WTO memenangkan Indonesia } \\
\text { dalam kasus ini namun Korea tidak menerima }\end{array}$ \\
\hline
\end{tabular}

${ }^{32}$ Ibid., angka 10. 


\begin{tabular}{|l|l|}
\hline & putusan panel DSB \\
\hline $\begin{array}{l}\text { Sunset Review 22 } \\
\text { Desember 2006 }\end{array}$ & $\begin{array}{l}\text { Indonesia menerima DSB WTO untuk } \\
\text { melakukan perjanjian ulang terhada kasus ini }\end{array}$ \\
\hline Laporan Panel 2007 & $\begin{array}{l}\text { Panel DSB WTO kembali memenangkan } \\
\text { Indonesia }\end{array}$ \\
\hline Desember 2010 & $\begin{array}{l}\text { Korea Selatan benar-benar Memenuhi dengan } \\
\text { mencabut pengenaan bea masuk antidumping } \\
\text { asal Indonesia }\end{array}$ \\
\hline
\end{tabular}

Sumber: Departemen Perdagangan, 2010.

AB (appellate Body) telah melakukan menyelesaiakan berbagai kasus sengketa perdagangan antar negara anggota. Sebagaimana disampaikan dalam laporan tahunan tahun 2005, dilaporkan kasus yang terjadi antara tahun 1995 sampai dengan tahun 2005 sebagai berikut:

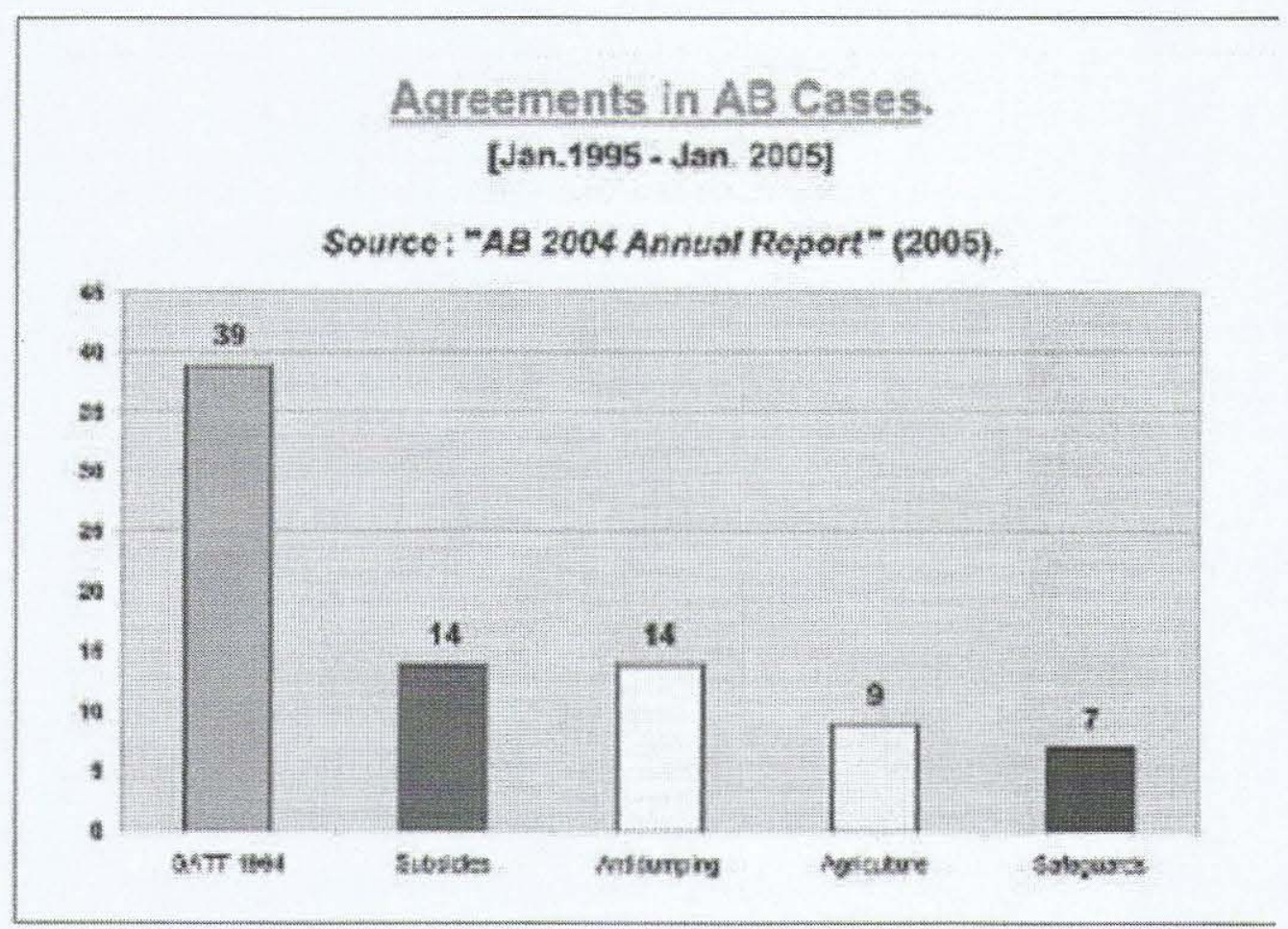

Pelanggaran atas GATT 1994 mencapai 39 kasus, subsidi dan antidumping sebanyak 14, pertanian 9 kasus dan safeguards sebanyak 7 kasus. ${ }^{33}$

Selanjutnya angka partisipasi negara-negara anggota yang berperkara melalui $\mathrm{AB}$ dalam kurun waktu 1995 sampai tahun 2005 didominasi oleh Amerika sebanyak 84, Uni Eropa71, Jepang 33, India 32, Mexico 17 dan

${ }^{33}$ WTO Annual Report, 2012, Dispute Settlement Body. 
Selandia baru 11 kasus. Untuk lebih jelasnya dapat dilihat dalam grafik batang berikut ini:

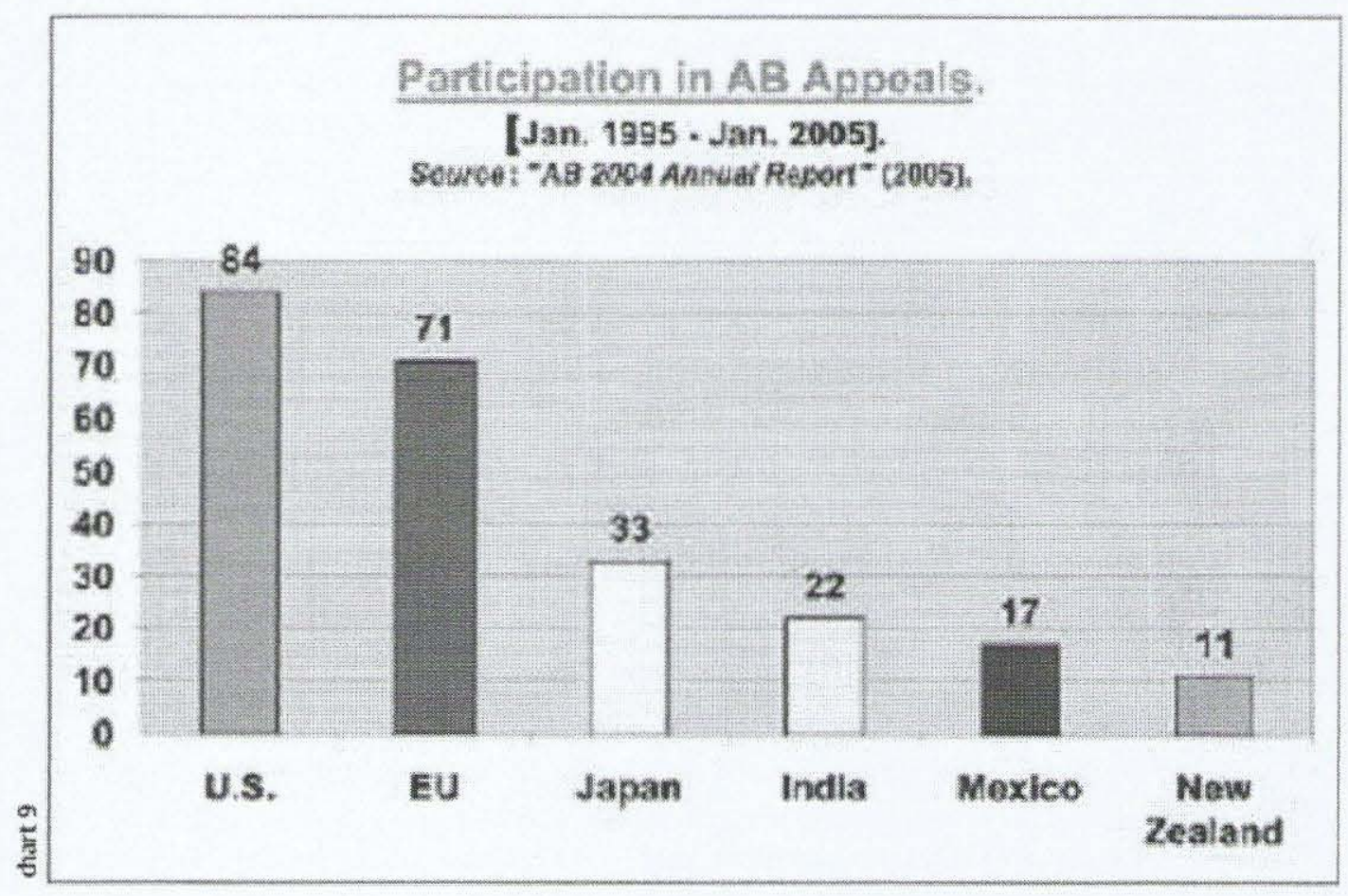

Negara Maju seperti Amerika, Uni Eropa dan Jepang merupakan 3 besar negara yang berpartisispasi dalam penyelesaian sengketa perdagangan melalui AB, sementara itu menurut laporan pada bulan Oktober 2004 terdapat 195 kasusu diajukan oleh negara maju dan 120 kasus oleh negara berkembang.

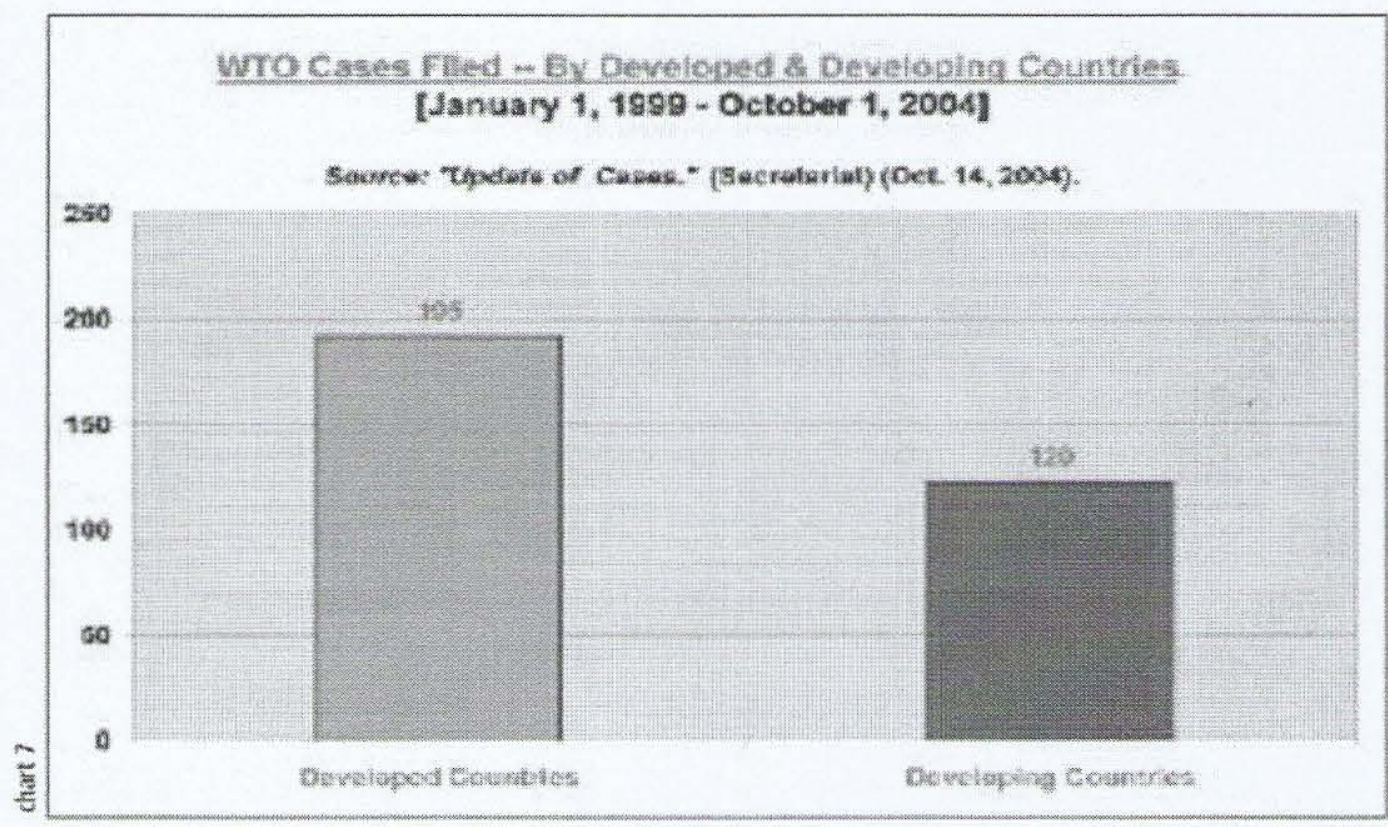


Selanjutnya bagaimana pengenaan sanksi oleh DSB dalam menyelesaiakan sengketa antar para pihak, dalam periode 1995 sampai tahun 2005 telah dikenakan sanksi oleh Panel maupun AB sebanyak 12, arbitrase 16 dan Otoritas DSB sebanyak 7 sanksi telah dijatuhkan.

Tahun 2011 DSB WTO menerima 8 notifikasi dari negara anggota WTO permohonan konsultasi berdasarkan DSU atau kurang dari setengah permohonan tahun sebelumnya yaitu 17 notifikasi pada tahun 2010 . Jumlahbtersebut merupakan jumlah terendah dalam sejarah WTO dan selanjutnya terjadi pada tahun 2005 yakni 12 notifikasi. Walaupun demikian DSB saat ini telah menngadopsi 8 laporan panel dan 5 laporan appellate Body termasuk edang menangani kasus besar mengenai sengketa Eni Eropa dan Air Bus dan Boeing Amerika Serikat. ${ }^{34}$

Akhir-akhir ini dalam periode 2001 sampai 2011 sejumlah permohonan konsultasi sebagai langkah pertama dalam mekanisme DSB dan menunjukan peningkatan partisispasi negara berkembang kedalam sistem DSB WTO. Dalam waktu 8 tahun dari periode 2001-2011, sejumlah permohonan konsultasi dari negara berkembang sama tau melebihi jumlah permohonan yang berasal dari negara maju. Peningkatan dan keaktifan negara berkembang dapat merupakan resultante dari eksistensi suatu lembaga yaitu Geneva-based Advisory Centre on WTO Law (ACWL). Lembaga tersebut merupakan lembaga independen tidak dipengaruhi oleh WTO dan telah banyak membantu baik negara berkembang maupun negara kurang berkembang terhadap 40 sengketa sejak lembaga tersebut berdiri. yaitu tahun 2001. ACWL dianggap telah banyak membantu dan sharing dengan berbagai negara anggota dan berkontribusi terhadap efektifitas siatem hukum yang diadopsi oleh WTO, khususnya prosedur sengketa dan realisasi dari pencapaian objektif WTO secara signifikan.

Berikut adalah Tabel anggota WTO yang terlibat dalam sengketa sejak tahun 1995-2001:

Tabel 1 negara bersengketa melalui WTO 1995-2011

\begin{tabular}{|l|c|c|}
\hline \multicolumn{1}{|c|}{ Nama negara } & $\begin{array}{c}\text { Pemohon/ } \\
\text { complainant state }\end{array}$ & $\begin{array}{c}\text { Tergugat/ } \\
\text { respondent state }\end{array}$ \\
\hline Antigua dan Barbuda & 1 & 0 \\
\hline Argentina & 15 & 17 \\
\hline Armenia & 0 & 1 \\
\hline Australia & 7 & 0 \\
\hline Bangladesh & 1 & \\
\hline
\end{tabular}

${ }^{34}$ World Trade Annual Report tahun 2011, Dispute settlement, <www.wto.org/disputes>, diakses tanggal 24 November 2010. 


\begin{tabular}{|c|c|c|}
\hline Belgia & 0 & 3 \\
\hline Brazil & 25 & 14 \\
\hline Canada & 33 & 17 \\
\hline Chili & 10 & 13 \\
\hline China & 8 & 23 \\
\hline Colombia & 5 & 3 \\
\hline Costa Rica & 5 & 0 \\
\hline Croasia & 0 & 1 \\
\hline Cezh Republic & 1 & 2 \\
\hline Denmark & 0 & 1 \\
\hline Dominican Republic & 0 & 7 \\
\hline Ecuador & 3 & 3 \\
\hline Egypt & 0 & 4 \\
\hline Elsalvador & 1 & 0 \\
\hline European Union & 85 & 70 \\
\hline Frace & 0 & 4 \\
\hline Germany & 0 & 2 \\
\hline Greece & 0 & 2 \\
\hline Guatemala & 8 & 2 \\
\hline Honduras & 7 & 0 \\
\hline Hongkong & 1 & 0 \\
\hline Hungary & 5 & 2 \\
\hline India & 19 & 20 \\
\hline Indonesia & 5 & 4 \\
\hline Ireland & 1 & 2 \\
\hline Japan & 14 & 15 \\
\hline Korea & 15 & 14 \\
\hline $\begin{array}{l}\text { Malaysia } \\
\text { Mexico }\end{array}$ & $\begin{array}{c}1 \\
21\end{array}$ & $\begin{array}{c}1 \\
14 \\
\end{array}$ \\
\hline Moldova & 1 & 1 \\
\hline Netherlands & 0 & 3 \\
\hline
\end{tabular}




\begin{tabular}{|c|c|c|}
\hline New Zealand & 7 & 0 \\
\hline Nicaragua & 1 & 2 \\
\hline Norway & 4 & 0 \\
\hline Pakistan & 3 & 2 \\
\hline Panama & 5 & 1 \\
\hline Peru & 3 & 4 \\
\hline Philippines & 5 & 6 \\
\hline Poland & 3 & 1 \\
\hline Portugal & 0 & 1 \\
\hline Romania & 0 & 2 \\
\hline Singapore & 0 & 1 \\
\hline Slovak Republic & 0 & 3 \\
\hline Soiuth Africa & 0 & 3 \\
\hline Spain & 0 & 2 \\
\hline Srilangka & 1 & 0 \\
\hline Sweeden & 0 & 1 \\
\hline Switzwerland & 4 & 0 \\
\hline Taipei- China & 3 & 0 \\
\hline Thailand & 13 & 3 \\
\hline Trinidad and Tobago & 0 & 2 \\
\hline Turkey & 2 & 8 \\
\hline Ukraine & 2 & 1 \\
\hline UK & 0 & 3 \\
\hline US & 98 & 113 \\
\hline Uruguay & 1 & 1 \\
\hline Venezuela & 1 & 2 \\
\hline Vietnam & 1 & 0 \\
\hline
\end{tabular}

Sumber: WTO Repport, 2012 


\section{Penutup}

\section{Kesimpulan dan Saran}

Berdasarkan penelitian dapat disimpulkan sebagai berikut:

1) Prosedur pengajuan gugatan ke DSB-WTO telah diatur secara tegas dan menyeluruh bagi negara anggota WTO yang bersengketa dengan ketentuan sebagai berikut:

Keterlibatan negara berkembang semakin meningkat dalam penyelesaian sengketa dagang antar negara anggota WTO. Dalam waktu 8 tahun dari periode 2001-2011, sejumlah permohonan konsultasi dari negara berkembang sama tau melebihi jumlah permohonan yang berasal dari negara maju. Peningkatan dan keaktifan negara berkembang dapat merupakan resultante dari eksistensi suatu lembaga yaitu Geneva-based Advisory Centre on WTO Law (ACWL),. Lembaga tersebut merupakan lembaga independen tidak dipengaruhi oleh WTO dan telah banyak membantu baik negara berkembang maupun negara kurang berkembang terhadap 40 sengketa sejak lembaga tersebut berdiri. yaitu tahun 2001. ACWL dianggap telah banyak membantu dan sharing dengan berbagai negara anggota dan berkontribusi terhadap efektifitas siatem hukum yang diadopsi oleh WTO, khususnya prosedur sengketa dan realisasi dari pencapaian objektif WTO secara signifikan. Pelanggaran atas GATT 1994 mencapai 39 kasus, subsidi dan antidumping sebanyak 14, pertanian 9 kasus dan safeguards sebanyak 7 kasus. Selanjutnya angka partisipasi negara-negara anggota yang berperkara melalui $\mathrm{AB}$ dalam kurun waktu 1995 sampai tahun 2005 didominasi oleh Amerika sebanyak 84, Uni Eropa71, Jepang 33, India 32, Mexico 17 dan Selandia baru 11 kasus.

2) Peranan DSB-WTO semakin meningkat yakni Tahun 2011 DSB WTO menerima 8 notifikasi dari negara anggota WTO permohonan konsultasi berdasarkan DSU atau kurang dari setengah permohonan tahun sebelumnya yaitu 17 notifikasi pada tahun 2010. Jumlah tersebut merupakan jumlah terendah dalam sejarah WTO dan selanjutnya terjadi pada tahun 2005 yakni 12 notifikasi. Walaupun demikian DSB saat ini telah menngadopsi 8 laporan panel dan 5 laporan appellate Body termasuk sedang menangani kasus besar mengenai sengketa Eni Eropa dan Air Bus dan Boeing Amerika Serikat. ${ }^{35}$

\section{Saran}

DSB-WTO seharusnya lebih memberikan perhatian terhadap negara berkembang, khsususnya dalam memberikan bimbingan dan konsultasi 
dalam mengajukan gugatan melalui DSB-WTO. Namun demikian SB-WTO masih banyak mengalami kendala dan kelemahan dalam implementasinya khususnya terhadap sengketa yang obyeknya merupakan barang yang tidak tahan lama. Maka diperlukan mekanisme yang lebih simpel dan cepat untuk kasus-kasus tertentu. Mekanisme penyelesaian sengketa melalui DSB WTO di sosialisasikan lebih luas khususnya bagi kalangan pelaku usaha baik BUMN, Swasta maupun industri lainya guna memahami dan mentaati norma penyelesaian sengketa internasional seperti DSB-WTO sehingga diharapkan para pelaku usaha memiliki langkah antisipatif ketika ada penyelidikan maupun gugatan dari pihak luar negeri baik untuk masalah perdagangan barang maupun jasa termasuk masalah hak kekayaan intelektual yang berkaitan dengan perdagangan internasional. 


\section{Daftar Pustaka}

\section{Buku}

Croome, John. Guide to the Uruguay Round Agreement, 1999.

Gijssels, Jan., Mark van Hoecke. Apakah Teori Hukum Itu, Terjemahan B. Erief Sidharta, Laboratorium Hukum Fakultas Hukum UNPAR, 2000.

Gilpin, Robert. The Political Economy of International relations, Princeton: University Press, 1987.

Irwin, D. An Intellectual History Of Free Trade, New Jersey: Princeton University Press, 1996.

Keohane, Robert O. After Hegemony: Cooperation and Discord in the World Political Economy, Princeton: University Press, 1984.

Koesters, Paul-Heinz. Tokoh-tokoh Ekonomi Mengubah Dunia, PemikiranPemikiran Yang Mempengaruhi Hidup Kita, Jakarta: Gramedia, 1987.

Krueger, Anne O. The WTO as an International Organization, 2000.

Liang, Margaret. The Real Politic of Multilateral Trade Negotiations from Uruguay to the Doha Round, Singapore Year Book of International Law, 2004.

Malanczuk, Peter. Akehurst Modern Introduction to International Law, Routledge, London, 1997.

Melvyn, E.G., and B. Krauss, The New Protectionism The Welfare State And International Trade, 1978.

Mill, J.S. Essays on Some Unsettled Questions of Political Economy, London: Parker. 1844. Press, 1990.

Radcliffe, Lord. The Law and its Compas, 1961.

Ricardo, D. Principles of Political Economy and Taxation, 1817, dalam J.M. Dents \& Sons Ltd, Everyman's Library, 1978.

Smith, A. An Enquiry into the Nature and Causes of the Wealth of Nations [1776], Book IV.ii.9, Oxford: Clarendon Press, 1979.

Spero, Joan Edelman. The Politics of International Economic Relations, 3rd edition, New York: tanpa penerbit 1985.

Soberi, Ekonomi Internasional, Teori, Masalah, dan Kebijakannya, Yogyakarta: BPFE UII, tanpa tahun.

Sukirno, Sadono. Pengantar Teori Ekonomi Mikro, Jakarta: Lembaga Penerbit Fakultas Ekonomi Universitas Indonesia, 1985. 


\section{Jurnal/Makalah/Laporan}

Agah, Yonov Frederick. "Dispute Settlement: Analysis By Frederick Agah WTO Dispute Settlement Body Developments in 2010", served as Chairman of the Dispute Settlement Body from 19 March 2010 to 24 February 2011.

Alessandrini, Donatella. "WTO And Current Trade Debate: An Enquiry Into The Intellectual Origins Of Free Trade Thought, International Trade Law \& Regulation International Trade”, Law Review, 2005, 11(2): 53-60.

Coing, H. Bretton. "Wood Confeence, European Public International Law Journal”, 1992: 494-495.

Garcia, Frank J. "Trade and Justice: Linking The Trade Lingkage Debates", University of Pennsylvania Journal of International Eonomic Law, 1998: 391, 404,-406, 411-413.

Hurabiell, Marie Louise. "Comment, Protectionism Versus Free Trade: Implementing the GATT Antidumping Agreement in the United States", 16 University of Pensylvania Journal International Business Law, 1995.

McGee, Robert W. "An Economic Analysis of Protectionism in the United States with Implications for International Trade in Europe", George Washington Journal International Law and Economic, 1993: 539-549.

"The Fatal Flaw in NAFTA, GATT and All Other Trade Agreements", New York Journal International Law \& Business, 1994: 549.

Pangestu, Mari. "Trade Reform, Deregulation and Competition Policy From an Indonesian Perspective, Frame Work For The Twenty First Century, Economic Conference”, USAID-LPEMFEUI, 1997.

Phillips, Michael M. \& Christopher Rhoads, "In a Repeat of Seattle, Economic Forum Draws Protests", Wall Street Journal, January. 31, 2000 .

Preamble WTO, "Marakesh Agreement", 1994.

Sally, Razeen. "What Future for the WTO in a Changing World Order?" in The World Trade Brief for the Fifth WTO Ministerial Conference, Cancun, 10-14 September, 2003.

Tiefenbrun, Susan. "Free Trade And Protectionism: The Semiotics of Seattle", Arizona Journal of International and Comparative Law, Spring, 2000.

Trebilcock, Michael J. "Law and Economics", The Dalhouse Law Journal, Vol.16, no.2 (Fall, 1993): 361-363.

United State Trade Restriction, Report, 2005. 
Wardhana, Ali. "Sustaining Economic Growth in Indonesia, Frame Work for the Twenty First Century", Economic Conference, USAID LPEMFEUI,1997.

WTO, World Trade Report, 2007.

\section{Koran}

Reich, Robert B. "NBC News/Wall Street Journal Poll”, dalam Financial Times, May, 201999.

Friedman, Thomas L. "The Real Losers, The Economist", Dec. 11, 1999, at 15. 1 Davos, 3 Seattles, New York. Times, January. 2, 2000, at A25.

Uchitelle, Louis. "From the Streets of Seattle to the Table at Davos", New.York. Times, Januari. 30, 2000, at 4.

\section{Internet}

Appellate Body Report, "United States-Measures Affecting Trade in Large Civil Aircraft", 892, WT/DS353/AB/R <http://www.wto.org/english/ tratop_e/dispu_e/353abr_e.pdf $>$, [hereinafter AB Report], diakses 12 Januari 2012 .

Bernard, Elaine. "A Short Guide to the WTO, the Millennial Round, and the Rumble in Seattle”, Znet Daily Commentaries, <http://www.zmag.org/ ZDaily/1999-11/24bernard.htm>, diakses 28 Maret, 2007.

"Hasil Negosiasi dalam Kesepakatan Doha di Qatar", Tahun 1990, <www.wto.org>, diakses 28 Maret,2007.

Moore, M. Globalisation: "The Impact Of The Doha Development Agenda On The Free Markets Process", US Chamber of Commerce, Florida, U.S., <www.wto.org/english/news_e/spmm_e/spmm77_e.htm>, diakses 28 Maret, 2007.

Panel Report, "United States-Measures Affecting Trade in Large Civil Aircraft (Second Complaint)", 3.1, WT/DS353/R, $<$ http://www.wto.org/english/tratop_e/dispu_e/353r_e.pdf $>$, diakses 12 Januari 2012.

"Request for Consultation with the European Union by the United States", WT/DS316/18, <http://docsonline.wto.org/DDFDocuments/t/WT/DS/ 316-19.doc>, diakses 9 Desember 2011.

Request for the Establishment of a Panel by the United States, "European Communities and Certain Member States-Measures Affecting Trade in Large Civil Aircraft", WT/DS318/23, <http://docsonline.wto.org/ DDFDocuments/t/WT/DS/316-23.doc>, diakses 3 April 2011. 
Request for Authorisation to Suspend Concessions by the United States, "European Communities and Certain Member States-Measures Affecting Trade in Large Civil Aircraft", WT/DS316/18 $<$ http://docsonline.wto.org/DDFDocuments/t/WT/DS/316-18.doc $>$, diakses 12 Januari 2012.

Ruggiero, R. Naskah disampaikan di hadapan Argentinian Council on Foreign Relations pada tanggal 10 September 1996 di Buenos Aires. Diakses dalam <www.wto.org/english/news_e/press96_e/ pr055_e.htm>, diakses 28 Maret, 2007.

Shiva, Vandana. "The Historic Significance of Seattle, Corporate Watch: The Watchdog on the web", 1 (dipublikasi tanggal 10 Desember 1999) $<$ http:// www.corpwatch.org/trac/feature/wto/6-shiva.htm>, diakses 28 Maret, 2007.

Tarleton, John. "Love and Rage in Seattle: The Day The WTO Stood Still", (dipublikasi 9 Desember, 1999) <http://www.cybertraveler.org/wto. html>, diakses 28 Maret 2007.

Understanding Between the European Union and the United States Regarding Procedures Under Articles 21 and 22 of the DSU, European "Communities and Certain Member States-Measures Affecting Trade in Large Civil Aircraft", WT/DS316/21, <http://docsonline.wto.org/ DDFDocuments/t/WT/DS/316-21.doc>, diakses 21 Januari 2012.

United Nations Treaty Series, 39, TIAS, No.1501,1947. dalam <www.un.org>, diakses tanggal 20 Februari 2008.

World Trade Annual Report 2011, "Dispute Settlement", <www.wto.org/disputes>, diakses tanggal 24 November 2010.

WTO Agreement on Subsidies and Countervailing Measures, 1867 U.N.T.S. 14, <http://www.wto.org/english/docs_e/legal_e/24-scm.pdf >, diakses 28 Maret 2007.

WTO Understanding on Rules and Procedures Governing the Settlement of Disputes, 1869 U.N.T.S. 401; 33 I.L.M. 1226, <http://www.wto.org/ english/docs_e/legal_e/28-dsu.pdf>, diakses 9 Desember 2011. 